\title{
Pembuatan KIT Sederhana Rangkaian Listrik Dinamis Sebagai Produk Akhir Pada Mata Kuliah Praktikum IPA
}

\author{
Dedi Riyan Rizaldi1* ${ }^{*}$ Kasmah Harwati1, Ziadatul Fatimah¹, Muh. Makhrus² \\ ${ }^{1}$ Program Studi Magister Pendidikan IPA, Program Pascasarjana Universitas Mataram, Lombok, Indonesia. \\ ${ }_{2}^{2}$ Program Studi Pendidikan Fisika, Fakultas Keguruan dan Ilmu Pendidikan Universitas Mataram, Lombok, Indonesia.
}

DOI: https://doi.org/10.29303/goescienceedu.v1i2.46

\section{Article Info}

Received : 8 Juli 2020

Revised : 17 November 2020

Accepted: 18 Desember 2020

\begin{abstract}
Abstrak: Pembelajaran fisika merupakan salah satu bagian dari ilmu sains tentunya harus mampu memfasilitasi peserta didik untuk melakukan praktikum atau percobaan dalam membuktikan konsep-konsep yang dipelajari. Salah satunya terkait materi listrik dinamis pada tingkat sekolah menengah. Namun masih banyak sekolah yang belum memiliki alat praktikum yang mampu memfasilitasi peserta didik dalam mempelajari materi listrik dinamis. Oleh karena itu penulisan artikel ini bertujuan untuk menjelaskan proses pembuatan KIT sederhana rangkaian listrik dinamis sebagai produk akhir pada mata kuliah praktikum IPA. Proses pembuatan KIT ini terdiri dari tiga tahapan yaitu persiapan, pelaksanaan, dan uji coba. Berdasarkan kegiatan yang telah dilakukan diperoleh bahwa 1). Proses pembuatan KIT rangkaian listrik dinamis terbagi menjadi dua bagian yaitu pembuatan set alat dan box penyimpanan, serta 2). Kegiatan-kegiatan praktikum yang dapat menggunakan KIT rangkaian listrik ini antara lain pengukuran besar GGL pada baterai, pengukuran tegangan dan kuat arus listrik, serta rangkaian seri dan paralel.
\end{abstract}

Kata Kunci: KIT Sederhana; Listrik Dinamis; Praktikum IPA

Abstract: Learning physics is of course a part of science and should be able to facilitate students to do lab sessions or experiments to prove the concepts learned. One of them relates to dynamic electricity at the secondary level. However, there are still many schools that do not have practical tools that can assist students in learning dynamic electricity equipment. Therefore, the writing of this article is to explain the process of making a simple KIT dynamic electrical circuit as the final product in the science practicum course. The process to create this KIT consists of three stages, namely preparation, implementation and testing. Based on the work carried out, this appears 1). The process of making a dynamic electrical circuit KIT is divided into two parts, namely making tool sets and storage boxes, and 2). Practical activities that can use this electrical circuit KIT include measuring the size of GGL on the battery, measuring the voltage and electrical current, as well as series and parallel circuits.

Keywords: Simple KIT; Dynamic electricity; Natural Science Practicum

\section{Pendahuluan}

Perkembangan ilmu pengetahuan dan teknologi telah mengalami kemajuan yang sangat pesat, keadaan ini telah berimbas disemua bidang kehidupan manusia dan salah satunya adalah bidang pendidikan. Fisika merupakan salah satu mata pelajaran dalam ilmu sains yang menekankan tidak hanya hasil melainkan bagaimana proses yang terjadi di dalam pembelajaran itu sendiri (Chodijah, et al., 2012). Mata pelajaran fisika 
memiliki beberapa tujuan yang dapat menjadi faktor pendukung bagi peserta didik dalam menghadapi persaingan yang terus mengalami perubahan khususnya pada Abad ke-21 saat ini. Tujuan tersebut diantaranya mengembangkan pengalaman untuk merumuskan masalah, mengajukan dan menguji hipotesis melalui percobaan, merancang instrumen percobaan, mengumpulkan, mengolah, dan menafsirkan data, serta mengkomunikasikan hasil percobaan baik secara lisan atau tertulis (Budiyono dan Hartini, 2016; Nurussaniah, 2016). Pernyataan tersebut sejalan dengan pendapat Suana (2017) bahwa fisika adalah ilmu pengetahuan yang dibangun dari pengamatan dan eksperimen, sehingga sudah seharusnya para pendidik membelajarkan fisika berbasis metode ilmiah atau biasa dikenal dengan pendekatan ilmiah (Scientific Approach).

Listrik dinamis merupakan salah satu materi pembelajaran yang disampaikan pada peserta didik tingkat sekolah menengah. Listrik dinamis merupakan listrik yang mengalir disebabkan karena adanya pergerakan muatan persatuan waktu yang disebut sebagai arus listrik. Arus listrik ini berasal dari pergerakan eletron yang terus-menerus dari kutub negatif menuju kutub positif atau jika yang diamati pergerakan arus secara umum maka bergerak dari kutub positif dengan potensial tinggi menuju kutub negatif dengan potensial rendah. Dua kondisi yang memiliki beda potensial bisa menyebabkan munculnya arus listrik, dengan catatan bahwa keduanya dihubungkan dengan suatu penghantar (rangkaian dalam keadaan tertutup) (Serway dan Jewett, 2004; Giancoli, 2014; Wahyudi, 2014). Karena yang dibahas pada materi ini adalah objek yang tidak dapat diamati secara langsung oleh peserta didik sehingga akan sangat sulit dalam proses pembelajaran jika hanya berdasarkan teori. Oleh karena itu diperlukannya kegiatan praktikum untuk memperkuat pemahaman peserta didik dalam mengkaji konsep listrik dinamis. Jufri (2013) menyatakan bahwa proses pembelajaran akan bermakna jika dilakukan oleh, dari, dan untuk peserta didik.

Menurut Saefullah, et al., (2018) bahwa keterampilan-keterampilan yang diperoleh melalui kegiatan praktikum sendiri dapat berupa keterampilan membuat rangkaian listrik, keterampilan menggunakan alat-alat ukur listrik, keterampilan memilih metode pengambilan data pengukuran yang tepat, keterampilan mengolah data serta keterampilan lainnya. Kegiatan praktikum fisika ini dilakukan dengan harapan untuk mendukung peningkatan kualitas pembelajaran yang masih terkendala oleh kurangnya atau bahkan tidak adanya jumlah alat praktikum yang dimiliki oleh sekolah. Menurut Manurung dan Sinambela (2018), bahwa keberadaan alat peraga dan praktikum untuk pembelajaran IPA sangat dibutuhkan. Kebutuhan tersebut sesuai dengan hakekat ilmu IPA yang meliputi produk, proses, aplikasi dan sikap.

Praktikum IPA merupakan salah satu mata kuliah yang terdapat pada program studi magister pendidikan IPA. Mata kuliah ini memfasilitasi mahasiswa untuk mampu melakukan kegiatan praktikum di tingkat sekolah menengah, salah satunya pada mata pelajaran fisika. Selain itu produk akhir yang diharapkan dari mata kuliah ini khusus untuk konsentrasi fisika adalah mahasiswa mampu merancang dan membuat alat praktikum sederhana namun dapat diterapkan pada pembelajaran ditingkat sekolah menengah. Berdasarkan permasalah tersebut maka penulis membuat suatu KIT sederhana rangkaian listrik dinamis dimana semua alat dan bahannya dapat diperoleh dengan mudah, sehingga pengadaannya dapat diterapkan oleh pendidik pada tingkat sekolah menengah.

\section{Metode}

Proses pembuatan KIT sederhana rangkaian listrik dinamis dilakukan melalui beberapa tahapan antara lain

\section{Tahap Persiapan}

a. Alat dan Bahan Papan Rangkaian Listrik

Alat-alat yang digunakan antara lain 1 unit gunting, 1 unit gergaji, 1 unit catu daya, dan 1 unit basicmeter. Sedangkan bahan-bahan yang digunakan antara lain 1 unit resistor $47 \mathrm{ohm}, 1$ unit papan kayu $(1,5 \mathrm{~m} \times 1,5 \mathrm{~m}), 1$ unit papan alas rangkaian $(27 \mathrm{~cm} \times 26$ $\mathrm{cm} \times 0,7 \mathrm{~cm}), 2$ unit bola lampu E10 2,5 volt, 2 unit vitting lampu, 20 unit kabel penghubung, 100 unit soket banana, 2 unit saklar, 2 unit baterai 3 volt, 2 unit dudukan baterai, dan 2 meter kawat tembaga.

\section{b. Alat dan Bahan Box Penyimpanan Papan Rangkaian Listrik}

Alat-alat yang digunakan antara lain 2 lembar amplas, 1 unit kuas, 1 unit gergaji, 1 unit penggaris, paku secukupnya, dan 1 unit palu. Sedangkan bahanbahan yang digunakan antara lain 1 unit papan kayu (atas) $(37,5 \mathrm{~cm} \times 31,5 \mathrm{~cm} \times 2 \mathrm{~cm}), 1$ unit papan kayu (alas) $(34 \mathrm{~cm} \times 27,5 \mathrm{~cm} \times 2 \mathrm{~cm}), 2$ unit papan kayu (samping) $(10 \mathrm{~cm} \times 37,6 \mathrm{~cm} \times 2 \mathrm{~cm})$, dan pernis secukupnya. 
c. Desain Papan Rangkaian Listrik

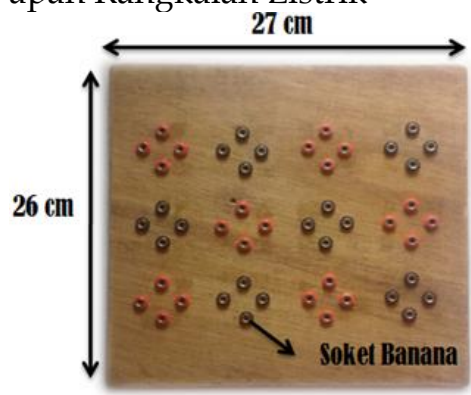

Gambar 1. Desain Papan Rangkaian Tampak Atas

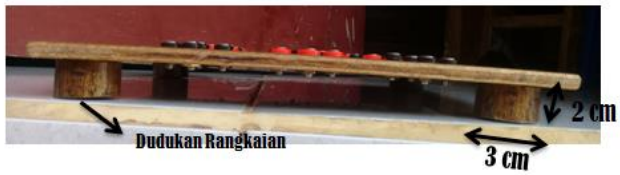

Gambar 2. Desain Papan Rangkaian Tampak Samping

\section{Tahap Pembuatan}

a. Proses Pembuatan Papan Rangkaian Listrik

Langkah-langkah dalam proses pembuatan papan rangkaian listrik dinamis antara lain:

1) Siapkan alat dan bahan yang digunakan.

2) Lubangi papan kayu sebagai papan rangkaian listrik sesuai dengan jumlah soket kabel yang akan dibuat seperti pada gambar berikut.

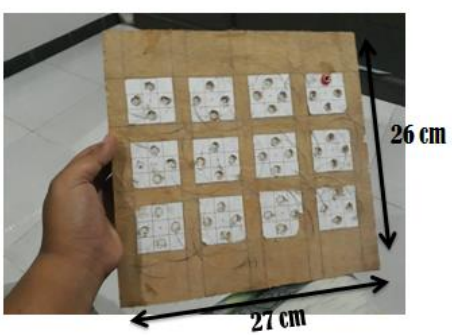

Gambar 3. Proses Pembuatan Lubang pada Papan Rangkaian

3) Letakkan soket banana ke dalam masing-masing lubang yang telah disediakan.

4) Hubungkan masing-masing soket banana dengan menggunakan kawat tembaga pada bagian bawah papan seperti gambar berikut.

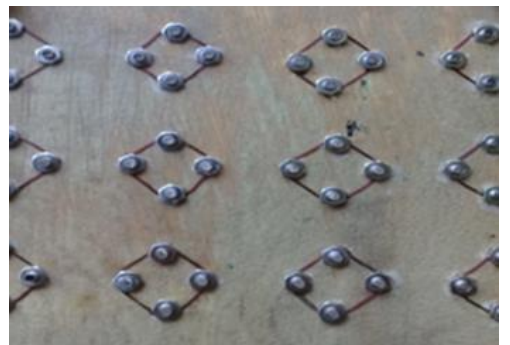

Gambar 4. Tampilan Bagian Bawah Papan Rangkaian Listrik
5) Buatlah komponen tambahan seperti kabel penghubung, dudukan saklar, dudukan lampu, dan dudukan resistor seperti gambar berikut.

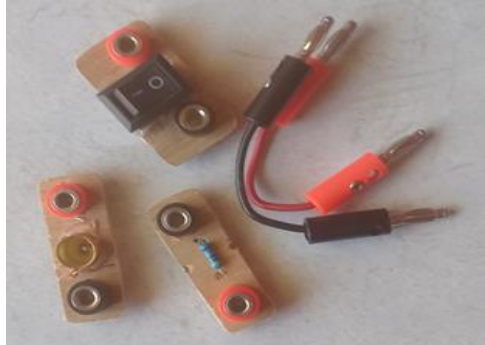

Gambar 5. Komponen-komponen Tambahan

6) Buatlah 4 unit dudukan pada masing-masing sudut papan rangkaian listrik.

7) Lakukan proses pewarnaan menggunakan pernis agar menghasilkan tampilan yang menarik dan bersifat tahan lama seperti gambar berikut.

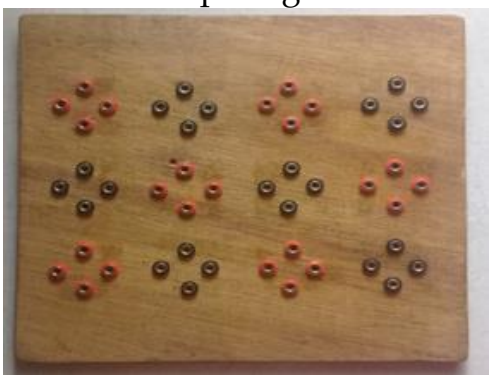

Gambar 6. Tampilan Akhir Papan Rangkaian Setelah diberikan Pernis

b. Proses Pembuatan Box Papan Rangkaian Listrik Langkah-langkah dalam proses pembuatan box papan rangkaian listrik dinamis antara lain:

1) Siapkan alat dan bahan yang digunakan.

2) Hubungkan 4 papan kayu sesuai ukuran menjadi sebuah balok seperti pada gambar berikut.

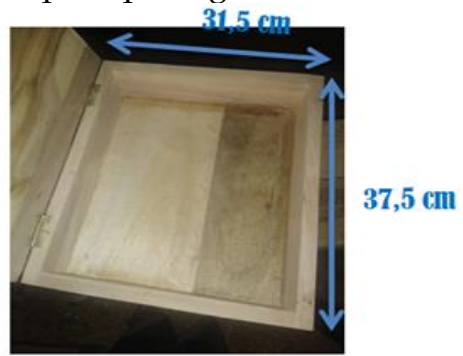

Gambar 7. Tampilan Box Set Papan Rangkaian Listrik

3) Haluskan seluruh bagian papan menggunakan amplas sebelum dilakukan proses pewarnaan.

4) Lakukan proses pewarnaan pada box menggunakan pernis.

5) Keringkan box di bawah sinar matahari agar mempercepat proses pengeringan.

6) Tambahkan beberapa komponen seperti pemegang box dan kunci gembok seperti pada gambar berikut. 


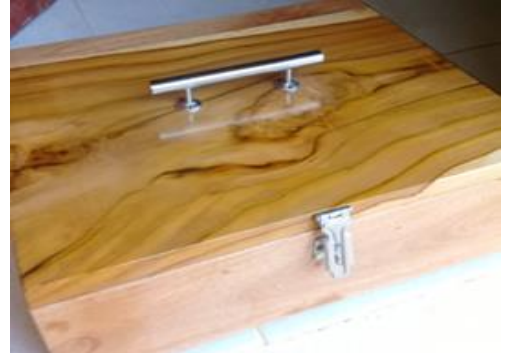

Gambar 8. Box KIT Sederhana Rangkaian Listrik Dinamis

\section{Tahap Uji Coba}

Set alat yang sudah dibuat kemudian dilakukan uji coba untuk mengetahui tingkat kinerja alat dengan melalukan beberapa kegiatan seperti.

a. Pengukuran nilai GGL pada baterai.

b. Pengukuran besar tegangan dan arus listrik.

c. Rangkaian seri dan paralel.

\section{Hasil Dan Pembahasan}

\section{Pengukuran Nilai GGL pada Baterai.}

Pengukuran Nlai GGL pada baterai dilakukan dengan jumlah baterai sebanyak 1 dan 2 baterai. Hasil pengukurannya seperti Tabel 1 .

Tabel 1. Hasil Pengukuran GGL pada Baterai

\begin{tabular}{lcc}
\hline No. & Jumlah baterai & Nilai GGL \\
\hline 1. & 1 & 1,5 volt \\
2. & 2 & 3,0 volt \\
\hline
\end{tabular}

\section{Pengukuran Besar Tegangan dan Arus Listrik}

Kegiatan berikutnya adalah melakukan pengukuran tegangan dan kuat arus listrik denga lampu, pengukuran tegangan dan kuat arus listrik denga resistor. Hasil pengukuran dipaparkan pada Tabel 2 dan Tabel 3.

Tabel 2. Hasil Pengukuran Tegangan dan Kuat Arus Listrik Menggunakan Lampu

\begin{tabular}{llll}
\hline No & Sumber tegangan & $\begin{array}{l}\text { Tegangan } \\
\text { Listrik (V) }\end{array}$ & $\begin{array}{l}\text { Kuat arus } \\
\text { listrik (A) }\end{array}$ \\
\hline 1. & 1 buah baterai & 1,0 & 0,19 \\
2. & 2 buah baterai & 1,6 & 0,25 \\
\hline
\end{tabular}

Tabel 3. Hasil Pengukuran Tegangan dan Kuat Arus Listrik Menggunakan Resistor

\begin{tabular}{llll}
\hline No & Sumber tegangan & $\begin{array}{l}\text { Tegangan } \\
\text { Listrik (V) }\end{array}$ & $\begin{array}{l}\text { Kuat arus } \\
\text { listrik (A) }\end{array}$ \\
\hline 1. & 1 buah baterai & 1,4 & 0,025 \\
2. & 2 buah baterai & 3,0 & 0,050 \\
\hline
\end{tabular}

\section{Rangkaian Seri dan Paralel}

Kegiatan berikutnya adalah melakukan pengukuran tegangan dan kuat arus listrik denga lampu, pengukuran tegangan dan kuat arus listrik denga resistor. Hasil pengukuran dipaparkan pada Tabel 2 dan Tabel 3

Tabel 4. Hasil Pengukuran Tegangan dan Kuat Arus Listrik pada Rangkaian Seri

\begin{tabular}{llll}
\hline No. & Lampu & $\begin{array}{l}\text { Tegangan } \\
\text { Listrik }(\mathrm{V})\end{array}$ & $\begin{array}{l}\text { Kuat arus } \\
\text { listrik }(\mathrm{A})\end{array}$ \\
\hline 1. & A & 1,3 & 0,18 \\
2. & B & 0,7 & 0,18 \\
3. & AB (Total) & 2,2 & 0,18 \\
\hline
\end{tabular}

Tabel 5. Hasil Pengukuran Tegangan dan Kuat Arus Listrik pada Rangkaian Paralel

\begin{tabular}{llll}
\hline No. & Lampu & $\begin{array}{l}\text { Tegangan } \\
\text { Listrik }(\mathrm{V})\end{array}$ & $\begin{array}{l}\text { Kuat arus } \\
\text { listrik }(\mathrm{A})\end{array}$ \\
\hline 1. & A & 1,3 & 0,18 \\
2. & B & 1,3 & 0,22 \\
3. & AB (Total) & 1,6 & 0,40 \\
\hline
\end{tabular}

Kegiatan pembuatan KIT Rangkaian Listrik Dinamis dilaksanakan mulai dari Selasa, 24 September 2019 sampai 29 Oktober 2019 di Rumah Mahasiswa S2 Pascasarjana dan Laboratorium Fisika FKIP, Universitas Mataram. Tujuan dari kegiatan ini yaitu membuat sebuah alat praktikum fisika sederhana yang dapat dijadikan sebagai media pembelajaran untuk membantu pendidik dalam menjelaskan konsepkonsep yang terdapat dalam materi listrik dinamis khususnya pada rangkaian listrik tingkat Sekolah Menengah. Proses pembuatan alat praktikum ini terbagi menjadi dua tahap yaitu: 1) Pembuatan dan perakitan set alat rangkaian listrik yang terdiri dari papan rangkaian listrik, kabel penghubung, set lampu, set saklar, set hambatan, dan komponen lainnya; 2) Pembuatan box dengan menggunakan kayu yang berfungsi sebagai tempat penyimpanan set alat rangkaian listrik.

Set KIT sederhana rangkaian listrik dinamis yang telah dibuat kemudian digunakan atau dilakukan uji coba pada beberapa judul kegiatan praktikum yang dapat diterapkan dalam proses pembelajaran. Judul kegiatan praktikum tersebut antara lain yaitu 1). Pengukuran nilai GGL pada baterai, 2). Pengukuran besar tegangan dan kuat arus listrik, dan 3). Rangkaian seri dan paralel. Judul kegiatan praktikum disusun secara sistematis menyesuaikan dengan urutan submateri yang terdapat dalam materi listrik dinamis.

Kegiatan uji coba pertama berjudul pengukuran nilai GGL pada baterai dengan tujuan dapat melakukan proses pengukuran nilai GGL pada baterai menggunakan alat ukur tegangan listrik (voltmeter). Kegiatan ini terdiri dari dua kondisi dimana pada kondisi pertama hanya terdiri dari satu unit baterai sebagai sumber tegangan dan didapatkan nilai tegangan yang terbaca pada voltmeter sebesar 1,5 volt. 
Kondisi kedua menggunakan sumber tegangan sebanyak dua unit baterai yang disusun secara seri dan didapatkan nilai tegangan yang terbaca pada voltmeter sebesar 3 volt. Hasil pembacaan nilai tegangan ini sesuai dengan kapasitas baterai yang digunakan dalam kegiatan ujicoba alat yaitu sebesar 1,5 volt/unit sehingga jika menggunakan dua unit baterai yang disusun secara seri maka total kapasitas baterainya sebesar 3,0 volt.

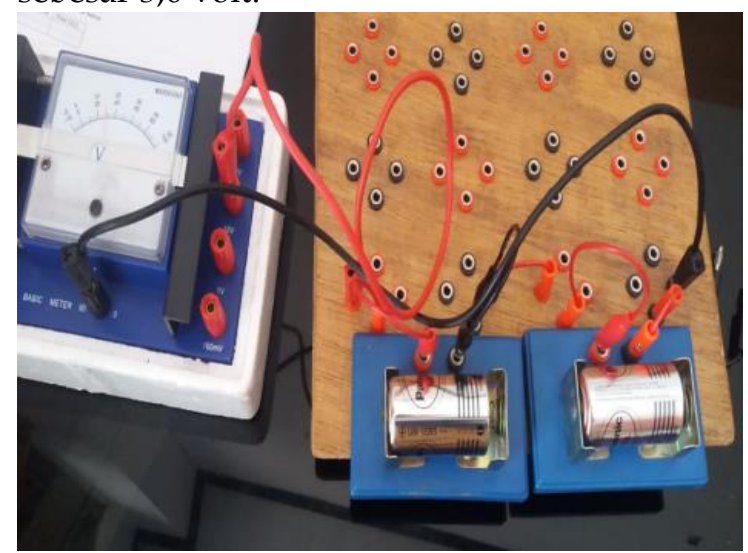

Gambar 9.Proses Pengukuran GGL pada Baterai

Kegiatan uji coba kedua berjudul pengukuran besar tegangan dan kuat arus listrik dengan tujuan dapat mengukur tegangan dan kuat arus listrik dalam rangkaian menggunakan voltmeter dan amperemeter. Kegiatan ini menggunakan dua bahan komponen hambatan yang berbeda yaitu menggunakan lampu dan resistor sebesar $47 \mathrm{ohm}$. Kegiatan pertama menggunakan hambatan lampu, dimana komponen dihubungkan secara seri dengan sebuah baterai dan didapatkan kuat arus dan tegangan secara berturutturut 0,19 A dan 1,0 V. Sedangkan pada saat menggunakan dua unit baterai didapatkan nilai kuat arus dan tegangan secara berturut-turut 0,25 A dan 1,6 V. Hal ini menggambarkan bahwa jika hambatan dibuat konstan atau tetap maka terjadi hubungan bahwa semakin besar tegangan yang diberikan pada suatu rangkaian menyebabkan arus yang mengalir dalam rangkaian tersebut juga akan semakin besar (Erfan, et al., 2020). Kemudian dengan cara yang sama lampu diganti menggunakan resistor sebesar $47 \mathrm{ohm}$, saat menggunakan sebuah baterai didapatkan kuat arus dan tegangan secara berturut-turut 0,025 A dan 1,4 $\mathrm{V}$ sedangkan saat menggunakan dua unit baterai didapatkan nilai kuat arus dan tegangan secara berturut-turut 0,050 A dan 3 V. Berdasarkan penggunakan resistor sebagai hambatan terlihat bahwa arus yang mengalir pada rangkaian semakin kecil jika dibandingkan dengan menggunakan lampu sehingga dapat diketahui bahwa hambatan yang terdapat pada resistor lebih besar dibandingkan pada lampu.

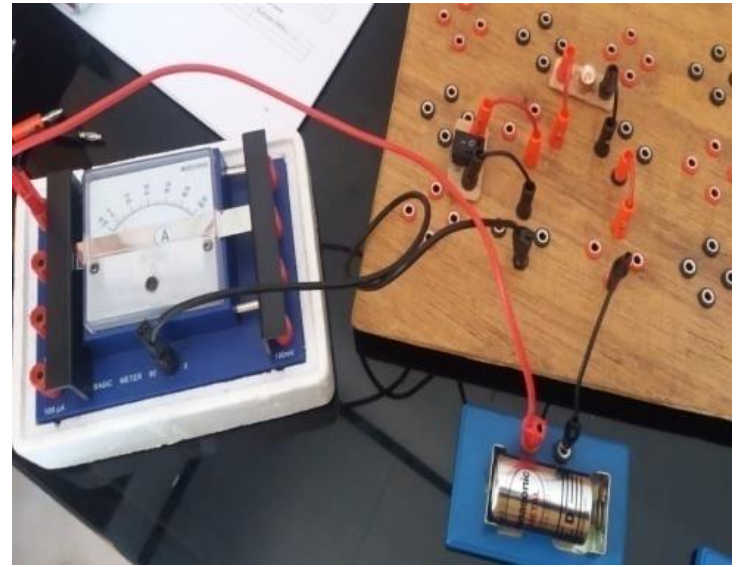

Gambar 10. Proses Pengukuran Tegangan dan Kuat Arus Listrik

Kegiatan uji coba terakhir berjudul rangkaian seri dan paralel bertujuan untuk menjelaskan karakteristik rangkaian seri dan pararel berdasarkan pengukuran kuat arus dan tegangan listrik dengan menggunakan alat ukur listrik. Kegiatan ini menggunakan dua buah lampu dan dua buah saklar (rangkaian paralel) yang disusun baik secara seri maupun paralel. Dua unit lampu yang disusun secara seri kemudian dihubungkan ke sebuah saklar yang sudah tersambung dengan sumber tegangan, kemudian didapatkan tegangan pada lampu A, B, dan AB (total) secara berturut-turut sebesar 1,3 V; 0,7 V; dan $2,2 \mathrm{~V}$. Sedangkan kuat arus yang terbaca pada rangkaian seri bernilai sama disemua komponen yaitu sebesar 0,18 A. Hasil tersebut sesuai dengan teori bahwa karakteristik dari rangkaian seri yaitu memiliki kuat yang sama di semua titik rangkaian dan tegangan total rangkaian merupakan hasil penjumlah antara tegangan masing-masing komponen (Rosman, et al., 2020).

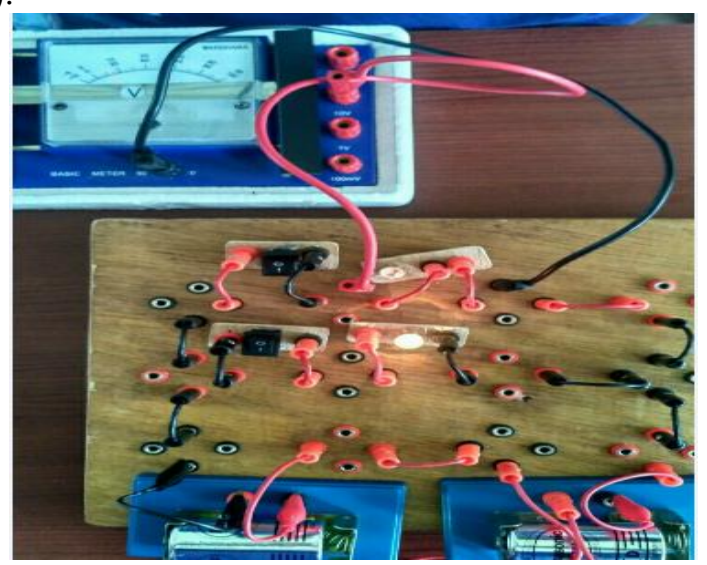

Gambar 11. Proses Pengukuran Rangkaian Seri dan Paralel

Langkah selanjutnya yaitu menyusun rangkaian paralel menggunakan dua unit lampu dan dua unit saklar dan dihubungkan langsung ke sumber tegangan (dua unit baterai), kemudian didapatkan tegangan 
pada lampu $A, B$, dan $\mathrm{AB}$ (total) secara berturut-turut sebesar 1,3 V; 1,3 V; dan 1,6 V. Sedangkan kuat arus pada lampu $A, B$, dan $A B$ (total) secara berturut-turut sebesar 0,18 A; 0,22 A; dan 0,40 A. Berdasarkan data tersebut untuk konsep arus pada rangkaian paralel sudah benar dimana arus total rangkaian merupakan hasil penjumlahan arus pada masing-masing komponen, namun terjadi sedkit perbedaan data pada tegangan yang terukur yang seharusnya pada semua titik rangkaian paralel memiliki tegangan yang sama. Kesalahan tersebut tentunya dapat disebabkan baik karena faktor pengamat maupun dari komponenkomponen yang digunakan khususnya baterai dan lampu.

\section{Kesimpulan}

Berdasarkan penjelasan yang telah diuraikan pada bagian sebelumnya dapat disimpulkan bahwa 1) Proses pembuatan KIT rangkaian Listrik Dinamis ini terbagi menjadi dua bagian yaitu pembuatan set alat dan box penyimpanan. 2) Kegiatan-kegiatan praktikum yang dapat menggunakan KIT rangkaian listrik ini antara lain pengukuran besar GGL pada baterai, pengukuran tegangan dan kuat arus listrik, serta rangkaian seri dan paralel.

\section{Daftar Pustaka}

Budiyono, A., dan Hartini, H. (2016). Pengaruh Model Pembelajaran Inkuiri Terbimbing terhadap Keterampilan Proses Sains Siswa SMA. Wacana Didaktika. 4(2): 141-149.

Chodijah, S., Fauzi, A., dan Wulan, R. (2012). Pengembangan Perangkat Pembelajarn Fisika Menggunakan Model Guided Inquiry yang dilengkapi Penilaian Portofolio pada Materi Gerak Melingkar. Jurnal Pendidikan Pembelajaran Fisika. 1:1-19.

Erfan, M., Maulyda, M.A., Ermiana, I., Rachmatul, V., Hidayati., \& Ratu, T. (2020). Profil Kemampuan Perbedaan Rangkaian Seri dan Paralel Calon Guru Sekolah Dasar. Edu Sains: Jurnal Pendidikan Sains dan Matematika, 8(1), 13-21.

Giancoli, D. C. (2014). Fisika: Prinsip dan Aplikasi Edisi ke 7 Jilid 1. Jakarta Erlangga.

Jufri, W. A. (2013). Belajar dan Pembelajaran Sains: Modal Dasar Menjadi Guru Profesional. Bandung: Penerbit Pustaka Reka Cipta.

Manurung, S. R., \& Sinambela, M. (2018). Perangkat Pembelajaran IPA Berbentuk LKS Berbasis Laboratorium. Jurnal Inovasi Pembelajaran Fisika. 6(1):80-87.
Nurussaniah, N. (2016). Penerapan Metode Eksperimen Terhadap Aktivitas Dan Hasil Belajar Pada Materi Elastisitas Bahan. JIPF (Jurnal Ilmu Pendidikan Fisika). 1(2): 37-41.

Rosman, A., Risdayana., Yuliani, E., \& Vovi. (2020). Karakteristik Arus dan Tegangan pada Rangkaian Seri dan Rangkaian Paralel dengan Menggunakan Resistor. d'ComPutarE: Jurnal Ilmiah Information Technology. 9(2): 40-43..

Saefullah, A., Fakhturrokhman, M., Oktarisa, Y., Arsy, R.D., Rosdiana, H., Gustiono, V., \& Indriyanto, S. (2018). Rancang Bangun Alat Praktikum Hukum Ohm untuk Memfasilitasi Kemampuan Berpikir Tingkat Tinggi (Higher Order Thinking Skills). Jurnal Ilmiah Penelitian dan Pembelajaran Fisika. 4(2):81-90.

Serway, R.A., \& Jewett, J.W. (2004). Physics for Scientists and Engineers Fifth Edition. New York: W. H. Freeman and Company.

Suana, W. (2017). Pengembangan Perangkat Pembelajaran Listrik Dinamis Berbasis Virtual Experiment untuk Kuliah Teori dan Praktikum Terintegrasi. Jurnal Pendidikan Fisika. 5(1):46-61.

Wahyudi. (2014). Petunjuk Praktikum Elektronika Dasar 1. Mataram: Universitas Mataram. 